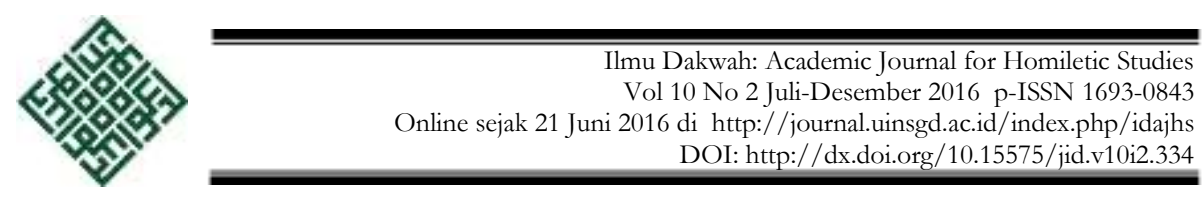

\title{
Komunikasi Dakwah Pesantren Tradisional
}

\author{
Taufik Rahman* \\ STAI AL-Jawami Bandung \\ taufikrahman@gmail.com
}

\begin{abstract}
This research is motivated by empirical data, the potential for problems in the field with regard to the growing problem of propaganda in the spread of Islam. Deployment is meant as the spread of Islam through the study of classical texts, recitals in taklim to male and female students who live in boarding Bustanul Wildan as well as to the communities in surrounding and also spread through the typical tradition traditional pesantren like tablilan, berzanji, Rajaban, Muludan and other events. Pesantren Bustanul Wildan be of interest to researchers as objects related research. Research conducted at the Islamic Schools Bustanul Wildan. The paradigm used in this study is a constructivist paradigm (qualitative). constructivist paradigm, uses the case study method. The conclusions of this research are: First, Pesantren Bustanul Wildan in the spread of Islam that is the communication patterns of action, interaction and transaction.
\end{abstract}

Keywords: Communication, Pesantren, Preaching Islam

\begin{abstract}
ABSTRAK
Penelitian ini dilatarbelakangi dengan problem dakwah yang berkembang dalam penyebaran Agama Islam di pesantren Bustanul Wildan melalui pengajian kitab-kitab klasik, pengajian di majelis taklim kepada santri dan santriwati yang tinggal maupun masyarakat di sekitaranya dan juga penyebaran lewat tradisi khas pesantren tradisional seperti tahlilan,berzanji, rajaban, muludan dan acara lainya. Penelitian ini menggunakan paradigma konstruktivis dengan metode Studi kasus. Sumber data diperoleh dari hasil wawancara, observasi, dan dokumentasi. Setelah data terkumpul, lalu dianalisis dengan teknik triangulasi. Kemudian data-data tersebut diolah dan direvisi kembali dengan menggunakan pendekatan kualitatif. Dalam pandangan penulis pesantren Bustanul Wildan dalam penyebaran agama Islam menggunakan pola komunikasi aksi, interaksi dan transaksi. Sedangkan bentuk komunikasi pesantren tradisional Bustanul Wildan adalah komunikasi interpersonal dan komunikasi kelompok.
\end{abstract}

Kata Kunci: Komunikasi, Pesantren, Dakwah Islam

Naskah diterima: 6 Sept 2016, direview 1 Nov 2016, disetujui: 14 Nov 2016 


\section{PENDAHULUAN}

Setiap agama yang timbul dalam kehidupan manusia di dunia dapat dipastikan mempunyai tujuan untuk menyebarkan ajaran kebenaran kepada seluruh umat manusia. Agama Islam sendiri dalam penyebaran syariat Islam telah ada sejak diutusnya Nabi Muhammad SAW dan usaha untuk menyebarkan kebenaran agama yang diyakini datang dari Tuhan dan menganutnya dianggap sebagai suatu tugas suci dan pengabdian kepada Tuhan Yang Maha Esa disebut dakwah.

Pesantren tempat yang relevan untuk menyiarkan agama Islam, maupun masalah-masalah sosial lainya, karena pelajaran yang diajarkan di pondok pesantren nantinya bisa dapat diterapkan oleh para santrinya dalam masyarakat di sekitarnya (Soleh, 1985: 46). Pondok pesantren sebagai salah satu lembaga dakwah Islam di Indoneisa, dan bahkan tetap dikembangkan sesuai dengan perkembangan zaman. Sejak masa awal penyebaran Islam, pesantren adalah saksi utama bagi penyebaran Islam di Indonesia. Perkembangan dan kemajuan masyarakat Islam di Indonesia tidak bisa terpisahkan dari peranan pesantren.

Pesantren yang sering kali dekenal dengan lembaga dakwah Islam yang ada diindonesia, yang telah memberikan banyak kontribusi dalam mencerdaskan anak bangsa yang berkaitan dengan intelektual maupun spiritual. Pesantren mempunyai pola komunikasi tersendiri yang tidak sama dengan pla komunikasi yang ada di sekolah-sekolah lainya. Dalam pola komunikasi yang ada pesantren, kyai merupakan seseorang pengendali bagi para santri-santri. Kyai mempunyai kedudukan komunikator yang kuat di hadapan para kyai. Kyai merupakan pempimpin dalam membangun komunikasi dakwah para santri-santrinya. Kyai bisa diupakan juga seorang raja yang memegang penuh teradap keberlangsungan suatu pesantren.

Pada saat ini, banyaknya pesantren tradisional yang telah berubah menjadi pesantren modern. Perubahan dari pesantren tradisional kepesantren modern tentunya akan merubah sistem pendidikan dan akan berdampak kepada komunikasi dakwah pesantren tersebut. Perubahan pesantren tradisional ke modern secara tidak langsung akan menghapus tradisi-tradisi pesantren tradisional yang telah ada sejak dulu. Salah satunya tradisi pesantren trasional adalah dengan sistem pengajaran sorogan, badongannya, memakai sarung,sorban dan lainya. Sistem pengajaran seperti sorogan dan badongan merupakan komunikasi dakwah

376 Ilmu Dakwah: Academic Journal for Homiletic Studies, Vol 10 No 2 | Juli-Des 2016 
pesantren tradisional kepada para santrinya. Sedangkan sarung, sorban merupakan komunikasi dakwah pesantren tradisional melalui simbolsimbolnya yang telah menjadi identitas tersendiri.

Penelitian ini dilakukan di Pesantren Bustanul Wildan. Penelitian yang berfokus kepada budaya komunikasi Pesantren tradisional dalam penyebaran agama Islam kepada para santrinya maupun masyarakat sekitar. Adapun hasil penelitian yang berhubungan dengan penelitian yang akan penelitian dilakukan, antara lain adalah: pertama, penelitian Baskoro Adi Nogroho yang berjudul "Manajemen pendidikan pondok Pesantren (Studi kasus pada pondok Pesantren aji mahasiswa Muhsin di Karapyak Wetan Jogyakarta). Penelitian ini bertujuan untuk mengetahui penerapan manajemen pendidikan pada pondok Pesantren dan mengertahui faktor-faktor yang mendukung dan menghambat penerapan manajemen pada pondok Pesantren Aji Mahasiswa Al Muhsin di Krapyak Wetan Yogyakarta.

Kedua, penelitian Arkanudin Budiyanto, dengan judul: "Pengaruh komunikasi pimpinan, gaya kepemimpinan dan motivasi terhadap prestasi kerja pegawai di pondok Pesantren (survey di pondok Pesantren modern Islam Assalaam Surakarta)". Penelitian ini bertujuan mengertahui signifikansi pengaruh komunikasi pimpinan,gaya kepemimpinan dan motivasi pegawai, baik secara persial maupun secara simultan. Metode yang digunakan adalah survey method kuantitatif.

Ketiga, penelitian Siti Aimah dengan judul: "Strategi Peningkatan Kualitas Pelayanan Pendidikan Pada Yayasan Pesantren Darussalam Blokagung Tegalsari Banyuwangi. Penelitian menjelaskan bahwa, Pesantren Darussalam termasuk Pesantren yang sudah menggunakan manajemen modern. Kyai sebagai tokoh utama mempunyai peran signifikan dalam membangun manajemen Pesantren dan mengembangkan eksistensinya, khususnya sebagai lembaga pendidikan Islam. Namun demikian karena telah berbentuk yayasan, penerapan manajemen modern dalam upaya peningkatan kualitas pelayanan publik tidak hanya menjadi tanggungjawab kyai sebagai top leader, tetapi juga menjadi tanggungjawab seluruh pengelola yayasan. Penelitian ini menggunakan deskriptif kualitatif. Ketiga penelitian tersebut, tentunya dapat memberikan gambaran awal bagi peneliti untuk lebih memfokuskan pada budaya komunikasi Pesantren tradisional dalam penyebaran agama Islam.

Pesantren Bustanul Wildan merupakan pesantren tradisional yang berdiri di tengah kota yaitu, kabupaten cileunyi Bandung. Pesantren ini didirikan oleh KH. Tajusubkie pada tahun 1948. Pesantren ini 
merupakan salah satu pesantren yang masih bisa konsisten dalam mempertahankan kebudayaan tradisionalnya, ditengah terpaan perkembangan jaman modern. Setelah KH. Tajusubkie meninggal dunia, Pesantren ini dilanjutkan oleh menantunya bernana KH. Yazid Bustomi. pesantren Butanul Wildan seperti pesantren tradisional lainya yang berfokus kepada pengajian kitab kuning, dengan target yang ingin dicapai membentuk santri menjadi muslim dan muslimah yang berakhlak baik, dan tujuan khususnya agar santri pandai membaca dan memahami kitab kuning sehingga bisa menyebarkannya kepada masyarakat (Wawancara dengan KH. Yazid Bustami).

Pesantren Bustanul Wildan merupakan salah satu pesantren tradisional yang ada di jawa barat. Pesantren yang mempunyai dua pimpimpinan pesantren yaitu kang Sepuh dan Kang Anom. Dalam sistem pendidikan di Bustanul Wildan terdapat banyak komunikasi dakwah, yang bertujuan untuk membina, memperbaiki dan mengajak kepada kebaikan.

Di pesantren Bustanul Wildan peran kyai begitu kuat dan tidak tergantikan. Kyai pmempunyai ciri khas tesendiri dalam bekomunikasi dengan para santrinya. Secara tidak langsung komunikasi kyai dengan santri merupakan salah satu komunikasi dakwah kyai kepada santrisantrinya. Dari komunikasi dakwah yang dilakukan kyai (komunikator) akan bisa mempengaruhi bahkan merubah pemikiran para santri. Cara seperti ini telah memulai pudar dimana banyaknya para pesantrenpesantren tradisional yang sudah berubah menjadi pesantren modern, dan akhirnya akan menyebabkan berubahnya cara berkomunikasi kyai dengan santri.

Komunikasi dakwah pesantren Bustanul Wildaan masih mempertahankan ketradisionalnya, salah satu bentuk komunikasi saat pembelajaran berlangsung melalui badongan,sorogan. Lebih dari itu, komunikasi dakwah pesantren Bustanul Wildan sarat dengan simbolsimbol; seperti sarung, kopiah dan surban.

Sampai saat ini pesantren Butanul Wildan masih bisa mempertahankan ketradisionalannya, walaupun banyak pesantren tradisional yang lainya sudah berganti baju menjadi pesantren modern dan pendidikan sekolah formal karena faktor tuntutan jaman saat ini. Oleh sebab itu, Pesantren Bustanul Wildan menjadi menarik bagi peneliti

378 Ilmu Dakwah: Academic Journal for Homiletic Studies, Vol 10 No 2 | Juli-Des 2016 
sebagai objek penelitian yang berhubungan dengan budaya komunikasi pesantren tradisional dalam penyebaran agama Islam.

Berdasarkan latar belakang di atas, maka masalahnya dapat dinyatakan: 'Bagaimana Budaya Komunikasi Pesantren Tradisional dalam Penyebaran Agama Islam di Pondok Pesantren Bustanul Wildan Cileunyi Kab. Bandung? Berdasarkan rumusan masalah penelitian tersebut, maka penelitian ini bertujuan untuk mengetahui pola komunikasi Pesantren tradisional Bustanul Wildan Cileunyi Kab. Bandung dan untuk mengetahui bentuk komunikasi Pesantren tradisional Bustanul Wildan Cileunyi Kab. Bandung.

Penelitian ini menggunakan teori Interaksi Simbolis milik George Herbert Mead dan teori simbol milik Susan Langer dan teori komunikasi tentang identita. Teori ini mempunyai pengaruh yang sangat besar dalam penelitian ini, karena di dalamnya memiliki tendensi-tendensi pemikiran yang kuat untuk menganalisis penelitian ini. Teori Interaksionisme simbolis, sebuah pengerakan dalam sosiologi, berfokus pada cara-cara manusia memberntuk makna dan susunan dalam masyarakat melalui percakapan (Littlejohn \& Foss, 2008: 231).

Teori Intraksi simbolik memfokuskan perhatiannya kepada caracara yang digunakan manusia untuk membentuk makna dan struktur masyarakat melalui percakapan. Teori intraksi simbolik juga mempunyai pengaruh dalam tradisi sosiokultural karena teori ini awalnya berangkat dari ide bahwa struktur sosial dan makna di ciptakan dan di pelihara dalam interasi sosial.

Perspektif interaksionisme simbolik berusaha memahami perilaku manusia dari sudut pandang subyek, perspektif ini menyarankan bahwa perilaku manusia harus dilihat sebagai proses yang memungkinkan manusia membentuk dan mengatur perilaku mereka dengan mempertimbangkan keberadaan orang lain yang menjadi mitra interaksi mereka.

Sedangkan interaksionisme simbolik mempelajari sifat interaksi yang merupakankegiatan sosial dinamis manusia. Bagi perspektif ini, individu bersifat aktif, reflektif, dan kreatif, menafsirkan, menampilkan perilaku yang rumit dan sulit perilakunya ditentukan oleh kekuatankekuatan atau struktur yang ada diluar dirinya. Oleh karena individu terus berubah maka masyarakat pun berubah melalui interaksi. Jadi interaksi lah yang dianggap sebagai variable penting yang menentukan perilaku manusia bukan struktur masyarakat. 
Teori komunikasi tentang identitas tergabunglah ketika kontek budaya individu, komunal dan publik. Menurut teori tersebut, identitas merupakan penghubung utama antara individu dan masyarakat serta komunikasi merupakan mata rantai memperoleh hubungan ini terjadi. tentu, identitas adalah "kode" yang mendifinisikan keanggotaan dalam komunikasi yang beragam. Kode yang yang terdiri dari simbol-simbol, seperti bentuk pakaian dan kepemilikan; kata-kata, seperti deskripsi diri atau benda yang biasanya dikatakan dan orang lain hubungkan terhadap benda-benda tersebut (Littlejohn \& Foss, 2008: 130).

Jadi, identitas komunikasi dakwah pesantren tradisional sangat melekat dalam pribadi santri maupun sang kyai. lewat teori ini akan mencari tahu bagaimana identitas-indentitas komunikasi dakwah pesantren tradisional yang mempunyai perbedaan dengan santri modern maupun murid sekolah formal.

\section{HASIL PENELITIAN DAN PEMBAHASAN}

\section{Pola komunikasi dakwah Pesantren Bustanul Wildan}

Komunikasi dakwah mengarah kepada pola atau bentuk komunikasi dalam menyampaikan pesan dakwah. Ada tiga pola komunikasi yang Diutarakan oleh Sudjana dan Rivai dalam bukunya, yaitu: pola komunikasi aksi, interaksi dan transaksi (Sudjana dan Rivai, 2003: 45).

Setelah melakukan pengamatan/obsevasi dan wawancara mendalam maka komunikasi dakwah pesantren tradisional dalam penyebaran agama Islam bisa melalui tiga pola komunikasi. Ketiga pola komunikasi tersebut berupa sistem pengajaran yang ada dipesantren Bustanul Wildan. ketiga sistem pembelajaran itu adalah sistem badongan, Sorogan dan bathsul masa'il.

Pola komunikasi yang diterapkan dalam sistem pembelajaran di pesantren akan mempengaruhi cara komunikasi dakwah para santri. Dari komunikasi tersebut akan terbentuknya tradisi dipesantren dalam medakwahkan agama Islam. Setiap pesantren tradisional maupun modern mempunyai cara tersendiri dalam melakukan komunikasi dakwah. 
Pertama, Pola Komunikasi aksi, yaitu, Pasaran dan badongan merupakan metode pembelajaran yang mempunyai kesamaan satu sama lain. Proses komunikasi di pesantren Bustanul Wildan dalam pembelajaran seperti badongan dan pasaran adalah komunikasi secara aksi. Komunikasi secara aksi berasumsi bahwa seseorang hanyalah pengirim atau penerima tidak ada balasan interaksi didalam komunikasi tersebut. Komunikasi secara aksi, dimana kyai mengajarkan kitab-kitab klasik, sedangkan santri hanya mendengarkan aksi tersebut. Santri tidak berani mengoreksi ataupun menegur kesalahan yang dibaca kyai.

Dalam pola komunikasi secara aksi, peran kyai sebagai pemberi aksi (pemberi pelajaran) aktif memberikan pelajaran kepada para santri dan juga aktif dalam menjelaskan isi kitab. sedangkan santri hanya bersifat pasif tanpa bisa memberikan feed back. pola komunikasi aksi ini telah menjadi tradisi yang tidak pernah dirubah karena pola komunikasi aksi kyai dalam proses pembelajaran ini telah berjalan sejak lama. Sampai saat ini komunikasi aksi melalui pembelajaran badongan dan pasaran masih dipertahankan.

Komunikasi dakwah dengan badongan kyai sangat berperan penting dalam menyampaikan pesan-pesan komunikasi dakwah kepada santri. Dalam sistem pembelajaran ini kyai menyampaikan bahasa komunikasi dakwah persuasif dengan media kitab. Dari kitab-kitab klasik tersebut kyai menyampaikan pesan komunikasi dakwah kepada santri. Pesan-pesan komunikasi dakwah melalui pola komunikasi ini selalu berkaitan dengan pesan keagamaan.

Komunikasi secara aksi merupakan komunikasi satu arah. Dimana komunikasi hanya berlangsung dari satu pihak saja, yaitu hanya dari pihak komunikator dengan tidak memberi kesempatan kepada komunikan untuk memberikan respon atau tanggapan. Sebagaimana yang dijelaskan oleh Mulyana dalam bukunya, bahwa bahwa komunikasi sebagai tindakan satu-arah (aksi) merupakan suatu pemahaman popular mengenai komunikasi manusia adalah komunikasi yang mengisyaratkan penyampaian pesan searah dari seseorang kepada seseorang lainnya baik secara langsung maupun melalui media (Mulyana, 2014: 67).

Sistem badongan di pesantren Bustanul Wildan menganut komunikasi satu arah atau komunikasi aksi. Komunikasi secara aksi terjadi di karenakan kyai merupakan komunikator yang dominan seperti yang dikatakan oleh Canggara bahwa dalam berkomunikasi sering kali ada seseorang yang lebih dominan (Cangara, 2012: 37). Komunikasi aksi ini menunjukkan bahwa kyai adalah seorang komunikator yang dominan, 
dimana kyai membaca kitab-kitab dan menjelaskan isi dari kitab-kitab kelasik tersebut.

Komunikasi secara aksi dalam badongan akan memebuat kyai menjadi berwibawa karena santri tidak akan berani mengkritik dan menolak pesan-pesan ajaran kyai. Pola komunikasi secara aksi terlihat bahwa kyai merupakan seorang raja otoriter tanpa memberikan ruang bagi para santrinya untuk merespon pesan-pesan komunikasi yang disampaikan oleh kyai.

Sebagaiman yang telah dijelaskan diatas pola komunikasi aksi dipesantren Bustanul Wildan dalam penyebaran agama Islam bisa digambarkan sebagai berikut

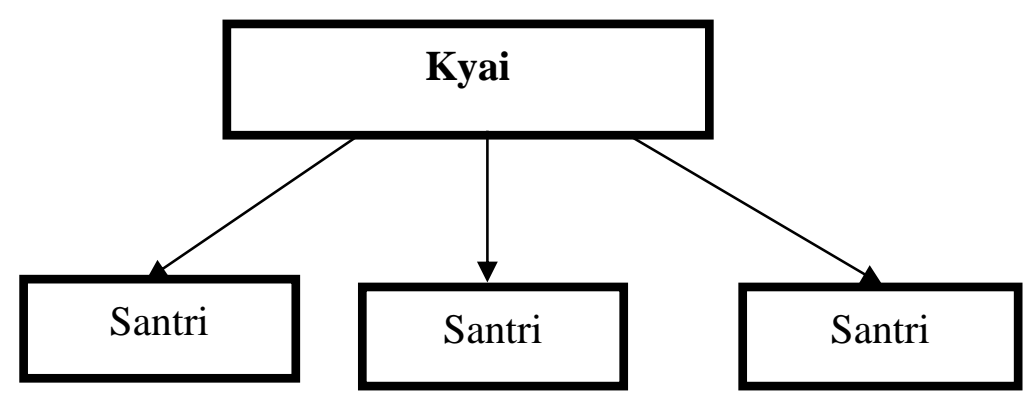

Gambar 1. pola komunikasi aksi pesantren Bustanul Wildan

Dari gambar diatas dapat dijelaskan bahwa kyai merupakan seorang aktor komunikator yang memegang kendali dalam penyebaran agama Islam kepada santri. Komunikasi Kyai kepada santri bersifat vertikal dimana kyai adalah seseorang yang mempunyai kedudukan tinggi di pesantren.

Kedua, Pola Komunikasi interaksi, Komunikasi secara interaksi merupakan komunikasi yang saling berinteraksi antara komunikator dengan komunikan. Dua dari aktor komunikasi ini saling mengirimkan dan membalas pesan. Dengan kata lain komunikasi interaksi ini merupakan komunikasi dua arah; dari pengrim ke penerima dan dari penerima ke pengirim. Komunikasi secara interaksi Komunikasi di pesantren Bustanul Wildan yang berpola interaksi bisa didapati saat proses pembelajaran sorogan dan bersilaturrahmi ke rumah kyai.

Pola komunikasi interaksi dalam sorogan adanya interaksi antara kyai dengan santri. Proses interaksi ini sering terbangun di sistem sorogan

382 Ilmu Dakwah: Academic Journal for Homiletic Studies, Vol 10 No 2 | Juli-Des 2016 
adalah sistem pembelajaran yang khusus di sediakan bagi santri-santri yang serius ingin mendalami isi kitab yang diinginkan. Komunikasi secara interaksi akan membuat santri dan kyai saling mengenal dan bahkan bisa mejadi akrab.

Interaksi dalam proses pembelajaran sorogan bersifat formal, dimana santri hanya bertanya yang berkaitan tetang pembelajaran saja. santri tidak berani bertanya berlebihan santri hanya bertanya secukupnya. Interaksi yang terjadi bukan saja ketika dalam proses pembelajaran sorogan, akan tetapi ketika santri sedang bersilaturrahmi kerumah kyai. Tradisi bersilaturrahmi ke rumah kyai merupakan keiasaan yang sering dilakukan oleh santri. Ketika terjadinya silalturrahmi antara kyai dengan santri maka bentuklah interaksi antara kyai dan santri.

Interaksi melalui bersilaturrahmi dengan kyai sangat berbeda dengan interaksi sorogan. Pola komunikasi secara Interaksi ketika acara silaturrahmi dengan kyai, bersifat non formal. Bahkan, pesan komunikasi interaksi antara sorogan dan bersilaturrahmi pun jauh berbeda. Jika pesan komunikasi saat sorogan santri dan kyai mengunakan pesanpesan komunikasi yang berkaitan dengan pembahasan kitab saja. Akan tetapi bebeda dengan pesan komunikasi saat bersilaturrahmi yang terbuka dan dinamis.

Contoh interaksi telah dijelaskan diatas adalah pola komunikasi Interaksi yang sering ditemukan di pesantren. pola komunikasi interaksi menuntut adanya unpan balik dari antara pihak-pihak yang mengikuti interaksi tersebut. Pertukaran pesan komunikasi dalam proses interaksi itu bisa lewat bahasa verbal maupun non verbal Maka dari itu pola komunikasi interaksi antara santri dengan kyai bisa digambarkan sebagai berikut.

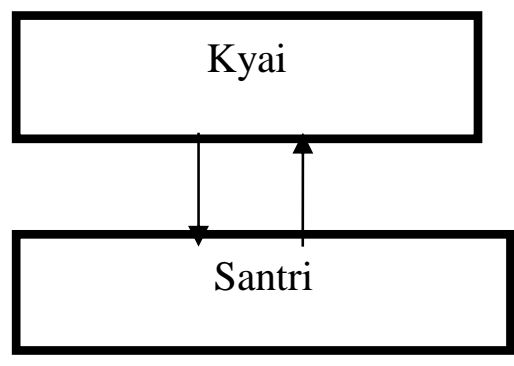

Gambar 2: Komunikasi interaksi pesantren Bustanul Wildan Dari gambar diatas, interaksi antara kyai dengan santri dalam penyebaran agam Islam bersifat vertikal. Pola komunikasi interaksi yang bersifat vertikal bahwa santri menganggap kyai mempunyai kehormatan yang tinggi. Komunikasi yang bersifat vertikal akan menyebabkan kyai 
menjadi dominan dalam berkomunikasi sendangkan santri hanya sesekali memberikan balasan (feed back).

Ketiga, Pola Komunikasi transaksi, komunikasi transaksi merupakan tindakan komunikasi yang mempunyai banyak arah dan saling mempengaruhi satu sama lain. Kontek pola komunikasi transaksi dalam penyebaran agama Islam di pesantren Bustanul Wildan ditemukan ketika adanya bathsul masai. Bathsul masail merupakan salah satu metode pembelajaran yang ada dipesantren Bustanul Wildan. Bathsul masail dipimpin oleh santri senior yang sudah mahir dalam keilmuan agama.

Komunikasi transaksi melalui Bathsul masail adanya saling mempengaruhi satu sama lain. sebagaimana pendapat canggara dalam bukunya, bahwa pada tingkatakan komunikasi transaksi dituntut dalam lataran yang lebih tinggi, lebih dinamis, dan kompleks. Dalam komunikasi transaksi santri bersama-sama membahas suatu permasalahan yang telah ditentukan untuk diselesaikan bersama-sama melaui komunikasi. Setelah adanya kesimpulan melalui interaksi maka akan diserahkan kepada seorang pemimpinan diskusi pengajian.

Komunikasi transaksi ini akan rumit dibanding pola komunikasi aksi dan interaksi. Kerumitan komunikasi transaksi dikarenakan para santri bebas menyuarakan pendapat dan argumentasi kepada para partisipan lainya. sebagaimana Mulyana menjelaskan dalam bukunya, bahwa Semakin banyak orang yang berkomunikasi, semakin rumit transaksi komunikasi yang terjadi.

Pesan komunikasi dalam metode bathsul masail ini santri bebas berargumen dan menunjukan perjelasan kepada para santri agar bisa mempengarhui santri yang lain, dan akhirnya mempunyai kesamaan makna. Pola komunikasi secara transaksi mengunakan pesan kepada seseororang untuk membangun kesamaan makna. Apa yang dikatakan oleh seseorang saat berkomunikasi transaksi akan mempengaruhi satu sama lain. Komunikasi transaksi ketika adanya bathsul masail (Musawarah) dipimpin oleh santri senior yang mahir dan dikontrol oleh sang kyai. Adapun komunikasi secara transaksi tersebut bisa digambarkan sebagai berikut:

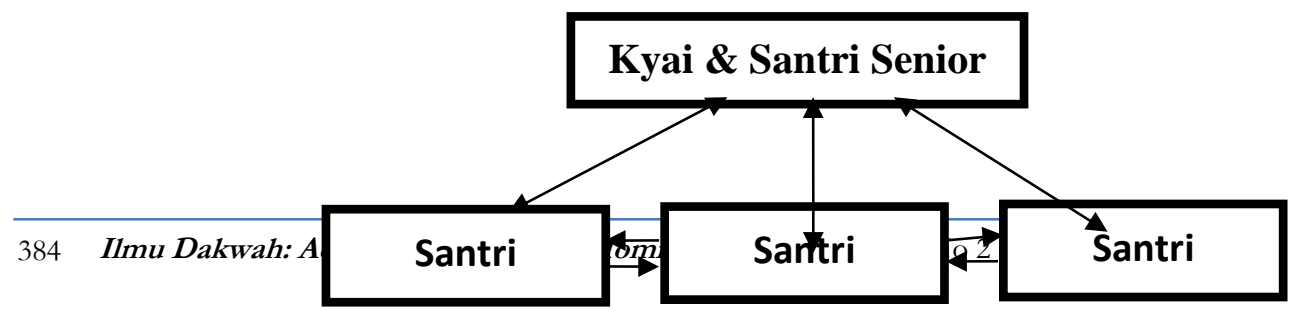


Gambar 3. Pola komunikasi transaksi dipesantren Bustanul Wildan

Gambar pola komunikasi diatas menunjukkan adanya interaksi antara para santri dengan santri yang lainya dalam pembahasan bathsul masail. Komunikasi transaksi melalui bathsul masail merupan salah satu metode penyebaran agama islam dipesantren Bustanul Wildan.

Dari ketiga pola komunikasi yang dijelaskan diatas dapat disimpulkan bahwa pola komunikasi pesantren tradisional dalam penyebaran agama Islam adalah pola komuniaksi aksi, pola komunikasi interaksi dan pola komunikasi transaksi.

Ketiga pola komunikasi ini pada akhirnya akan membentuk suatu pemikiran (mind) santri. Sedangkan terbentuknya suatu budaya menurut seorang ahli antropologi umumnya mencakup cara berpikir. (Koentjanigrat, 2000: 74).Cara berpikir pesantren itulah yang juga menjadikan pola komunikasi aksi dan interaksi dan transaksi yang ada di pesantren Bustanul Wildan.

Ketiga pola komunikasi diatas mempunyai keterkaitan dengan teori interaksionisme simbolik, dimana teori interkasionime simbolik terbentuk dari interaksi. Interaksi merupakan komunikasi. Komunikasi secara aksi, interaksi serta transaksi akan membentuk mind, self dan society. Jadi teori interaksionisme simbolik berfokus pada cara-cara manusia membentuk makna dan susunan dalam masyarakat melalui percakapan. (Littlejohn and Foss, 2008: 231) Percakapan itu antara santri dengan kyai melalui komunikasi aksi, interaksi dan transaksi. Percakapan itu akan memberikan makna bagi santri saat proses komunikasi dengan kyai.

Salah satu proses komunikasi antara kyai dengan santri saat proses pembelajaran (badongan, sorogan, pasaran) selalu mengunakan media kitab klasik. Media kitab klasik yang digunakan kyai merupakan tuntunan kyai dalam membentuk pemikiran (mind) dan konsep diri (self) santri. Salah satu kitab yang diajarkan dipesantren kitab tentang kefiqihan, kitab tetang alat dan akhlak tasawuf. Dalam proses interaksi ini kyai menyampaian isi pesan komunikasi dari kitab tersebut dan akhirnya santri yang memberikan makna dari pecakapan kyai melalui pengajian (sorogan, badongan, dan bathsul masail) dan bersilaturrahmi. ketiga pola komunikasi yang dilakukan oleh kyai akan membentuk pemikiran dan akan memberikan implikasi kepada perilaku santri. 
Pola komunikasi secara aksi memudahkan bagi kyai untuk mempengaruhi pikiran santri. Salah satu cara kyai membentuk mind santri secara aksi dengan melalui media pengajaran kitab klasik yang ajarkan dipesantren. Dengan melalui komunikasi secara aksi terus menerus dalam proses pembelajaran akan bisa merubah pola pikiran (mind) dan self diri santri.

Pola komunikasi aksi membuat santri pasif, akan tetapi santri bisa memberikan makna apa yang dikomunikasi kyai kepada santri. Maka itu, simbol-simbol verbal maupun nonverbal yang diajakarkan oleh kyai melalui komunikasi dalam proses pembelajaran bisa memberikan makna kepada santri. makna itu bisa berupa pengertian santri terhadap keilmuan agama, akhlak dan lainya, yang diajarkan kyai saat pembelajaran.

Komunikasi secara interaksi antara kyai dan santri akan memberikan contoh perilaku yang baik bagi santri. Interaksi antara kyai dan santri akan sama-sama memberikan makna dan akhirnya membentuk pemikiran yang sama dengan kyai. Konsep diri santri tradisional yang derhana dan religius merupakan dari hasil mencontoh pribadi sang kyai. karena esensi teori interaksi simbolik adalah membentuk pribadi seseorang lewat interaksi (Ritzer \& Goodman, 2010: 290).

Sedangkan komunikasi secara transaksi, bahwa dalam teori interaksionisme simbolik seseorang itu dipengaruhi atau dibentuk dari lingkungan sosialnya (society). Teori ini interaksi simbolik memahami bagaimana manusia bersama dengan manusia lainya, menciptakan dunia simbolik dan bagaimana nantinya simbol membentuk perilaku manusia. Lingkungan sosial pesantren yang merupakan masyarakatnya agamis serta kehidupan yang serba sederhana akan membentuk pribadi para santri yang agamis dan berkepribadian sederhana.

Lingkungan pesantren yang baik akan berpengaruh kepada konsep diri seseorang yang berada didalamnya. Sebagaimana yang dikatakan oleh mulyana bahwa pada hakekatnya tiap manusia bukanlah "barang jadi" akan tetapi merupakan barang yang akan jadi. Ketika seorang santri baru masuk di Bustanul Wildan pasti akan menemukan banyak bermacam keanehan akan karena konsep dirinya yang tidak sama dengan konsep diri santri-santri yang telah dulu mesantren.

Akan tetapi saat berjalannya waktu dengan melalui interaksiinteraksi maka pribadi/ konsep diri itu akan terbentuk dan akhirnya akan mempunyai konsep diri yang sama dengan para santri lainya. maka jelaslah bahwa interaksionisme simbolik merupakan teori komunikasi

386 Ilmu Dakwah: Academic Journal for Homiletic Studies, Vol 10 No 2 | Juli-Des 2016 
yang saling mempengaruhi individu saat bekomunikasi dengan komunitasnya.

Pesantren memang selalu identik dengan simbol-simbol keagamaan yang dipakai oleh mereka. Bahkan, dari simbol-sombol itu terdapat nilai-nilai yang terkandung dalam ajaran Islam. Bukan hanya sekedar meniru-niru kyainya memakai simbol-simbol tertentu, akan tetapi punya dasar tertentu yang bisa dipertanggung jawabkan. Simbol-simbol tersebut diperankan oleh para santri dan kyai. Simbol simbol ini hanya dimengerti oleh mereka-mereka yang hidup dalam lingkungan budaya tersebut. Sedangkan orang-orang yang hidup diluar kebudayaan pesantren sering kali tidak paham dari arti dari simbol-simbol tersebut.

Di pesantren Bustanul Wildan simbol-simbol komunikasi yang diperankan santri bukan saja dari atribut-atribut yang dipakai mereka, akan tetapi terdapat simbol-simbol dari bahasa keseharian mereka. Sebagaimana yang dikatakan Alo Liliweri dalam bukunya bahasa bukan saja hanya untuk mengambarkan pikiran dan perasaan, akan tetapi bahasa berguna untuk memaknakan simbol atau tanda yang telah diorganisasikan dalam sistem pembahasaan (Liliweri, 2008: 1).

Pesantren Bustanul Wildan merupakan pesantren tradisional yang mempunyai banyak simbol didalamnya adalah simbol-simbol yang dipakai oleh santri putra dan putri. Simbol-simbol itu bisa berupa kopiah/peci,surban dan sarung yang selalu dipakai santri putra Bustanu Wildan. Makna umum dari simbol kopiah,surban dan sarung adalah bentuk kezuhudan dan kelaziman bagi santri Bustnul Wildan.

Adapun makna khusus yang telah terbangun dipesantren Bustanul Wildan adalah untuk membedakan mana santri dengan yang bukan santri. Seseorang yang menggunakan simbol kopiah di lingkungan pesantren akan memberikan arti bahwa itu adalah santri. Akan tetapi, jika ada santri yang tidak memakai kopiah, lalu bertemu kyai maka kyai akan menggangap itu bukan santri. simbol-simbol khusus kopiah ini hanya dimengerti oleh para santri Bustanul Wildan.

Selain itu, simbol yang digunakan oleh santri putri adalah rok dan jelbab. Seorang wanita yang memakai rok dan jelbab dilingkungan pesantren adalah santri Bustanul Wildan akan tetapi jika ada yang memakai celana levis maka itu bukan santri, akan tapi merupakan teman santri. Simbol ini dipertegas oleh penelitian Gibbins dalam Alo Liliweri menunjukkan bahasa pendapat seseorang terhadap orang lain sering kali didasarkan pada pakaian yang mereka pakai (Liliweri, 2008: 1). Simbol seorang santri putra Bustanul Wildan adalah peci/kopiahnya sedangkan simbol dari seorang santri putri adalah jelbab dan pakaian rok. 
Simbol di pesantren bukan saja atribut yang dikenakan oleh para santri dan kyai, akan tetapi simbol itu berupa gerakan yang dilakukan oleh santri maupun kyai. sebagaimana yang dikatakan oleh samovar dalam bukunya“"Simbol bisa membentuk gerakan..." (Samovar, dkk, 2014: 30). Di pesantren simbol ketakziman santri ke kyai adalah dengan menunduknya santri ketika berjalan dihadapan kyai, tidak beraninya santri menatap mata kyai saat berlangsungnya interaksi, bahkan duduk santri berjauhan dengan kyai saat belangsungnya pembelajaran, santri duduk lebih rendah dengan kyai dan santri tidak berani bertanya sebelum kyai bertanya. Dari beberapa budaya komunikasi takzim santri kepada kyai yang disebutkan diatas itu merupakan simbol-simbol yang sering ditemukan dipesantren Bustanul Wildan.

Bahasa juga merupakan bagian dari simbol. Bahasa-bahsa yang berbentuk simbol hanya dimengerti oleh kalangan santri dan kyai. salah satu bahasa simbol itu adalah bahasa "mang" dan "kang". Bahasa panggilan "kang" dan "mang" yang sering digunakan oleh santri-santri Bustanul Wildan. Akan tetapi arti dari bahasa "kang" dan "mang" ini punya berbedaan. Bahasa simbol "mang" digunakan bagi santri yang seumuran. Sedang bahasa "kang" digunakan untuk santri yang lebih senior. Bahasa "mang" dan "kang" telah menjadi bahasa panggilan seharihari bagi santri Bustanul Wildan. simbol dari bahasa "mang" dan "kang" merupakan simbol penegasan antara santri senior dengan santri jenior.

Simbol bahasa panggilan bukan saja dikalangan santri akan tetapi kyai yang merupakan simbol kekuasaan pesantren tradisional juga mempunyai panggilan khusus. Para santri putra dan putri serta masyarakat disekitar mempunyai panggilan khusus untuk kyai. panggilan mereka adalah "kang sepub"dan "kang anom" panggilan "kang sepub" dan "kang anom" merupakan panggilan simbol bagi para santri dan masyarakat untuk membedakan mana kyai muda dengan kyai tua (sepuh). Simbol panggilan ini tidak sama dengan panggilan pesantren-pesantren lainya. setiap pesantren punya simbol-simbol panggilan khusus bagi kyai mereka masing-masing.

Simbol berupa bahasa yang sering digunakan oleh para santri saat proses komunikasi interpersonal dan kelompok adalah UL (usaha letik). Bahasa simbol UL(usaha letik) ini adalah bentuk pemaknaan tahlilan. Bagi santri Bustanul Wildan bahasa simbol UL (usaha letik) tidak aneh lagi dikalangan mereka. ketika seorang santri mengatakan UL (usaha letik) maka para santri langsung mempersipkan diri untuk ikut ke acara 
tahlilan tersebut. Seorang santri menegaskan bahasa lain dari tahlilan adalah UL (usaha letik).

Bahasa simbol UL (Usaha letik) ini hanya dimengerti oleh kalangan santri Bustanu Wildan saja karena simbol-simbol hanya diketahui oleh mereka yang satu budaya sebagaimana yang dikatakan Macionis dalam samovar: "Simbol merupakan segala sesuatu yang mengandung makna khusus yang diketahui oleh orang-orang yang menyebarkan budaya" (Samovar, dkk, 2014: 45-46).

Bahasa simbol yang terdapat dalam pola komunisi aksi,interaksi dan traksaksi akan memberikan makna bagi para santri. seperti diamnya kyai saat pembelajaran belangsung merupakan bentuk simbol yang diartikan oleh santri adalah kemarahan atau ketidak senangan kyai. Begitu juga simbol nonverbal santri yang menunduk saat berinteraksi dengan kyai merupakan makna ketakziman santri kepada kyai. Sebagaimana yang dijelaskan Langer menilai simbol sebagai suatu hal yang sangat penting dalam ilmu filsafat, karena simbol penyebab dari semua pengetahuan dan pengertian yang dimiliki manusia (Morissan, 2010: 156).

Selain itu, Salah satu simbol adalah pakaian yang dekenakan oleh masyarakat komunitas pesantren (santri, guru dan kyai). sebagaimana Langer mengatakan bahwa perasaan manusia dimediasikan oleh konsepsi, simbol dan bahasa. Simbol dan bahasa bisa sering ditemukan ke tiga pola komunikasi yang ada di pesantren Bustanul Wildan. Simbol itu bisa berupa verbal dan nonverbal . simbol yang ada dipesantren merupakan penunjukan makna yang hanya bisa dimengerti komunitas pesantren tersebut salah satu contoh adalah simbol kyai yang duduknya lebih tinggi dari santri saat pembelajaran berlangusng merupakan arti bahwa kyai mempunyai kedudukan tinggi dari santri.

Dari kedua teori intraksionisme simbolik dan simbol dapat disimpulkan dalam pembahasan tiga pola komunikasi dalam penyebaran agama Islam mempunyai keterkaitan dalam membentuknya pikiran,self dan society. Begitu juga teori simbol sangat berkaitan dengan simbolsimbol yang ada dipesantren. simbol-simbol komunikasi verbal maupun nonverbal yang menjadikan ciri khas unik dari pesantren tradisional. Penyebaran ajaran islam dipesantren Bustanul Wildan bisa berupa Simbol-simbol yang melekat pada diri kyai maupun santri.

\section{Bentuk komunikasi pesantren Bustanul Wildan}

Bentuk komunikasi ada komunikasi intrapribadi, interpersonal, kelompok, organisasi dan massa dan lainya. setelah melakukan penelitian melalui observasi dan wawancara dengan komunitas pesantren, maka bentuk komunikasi yang ada di pesantren Bustanul Wildan dalam 
penyebaran agama Islam mempunyai dua Bentuk komunikasi. yaitu; Komunikasi interpersonal dan komunikasi kelompok.

Di pesantren Bustanul Wildan mempunyai bentuk komunikasi tersediri dalam berkomunikasi dalam penyebaran agama islam. Adapun bentuk komunikasi di pesantren Bustanul Wildan dapat dijelaskan sebagai berikut: Komunikasi interpersonal kyai dan santri. Komunikasi interpersonal adalah komunikasi antara orang-orang secara tatap muka, yang memungkinkan setiap pesertanya menangkap reaksi orang lain secara langsung, baik secara verbal atau nonverbal (Mulyana, 2010: 81). Komunikasi interpersonal pesantren Bustanul Wildan mempunyai keunikan tersendiri. Komunikasi interpersonal di pesantren bisa bersifat verbal maupun nonverbal. Salah satu Bentuk komuniksi interpersonal dalam penyebaran agama di pesantren Bustanul adalah melalui silaturrahmi.

Komunikasi interpersonal di pesantren sering terjadi saat santri bersilaturrahmi (pamit pulang, minta doa dsb.) kerumah kyai ataupun saat berpapasan dijalan. Dalam proses komunikasi interpersonal santri diharuskan mempunyai etika saat berkomunikasi dengan kyai. Etika komunikasi interpersonal bisa berupa simbol verbal maupun nonverbal yang dipergunakan agar pesan komunikasi bisa dipahami oleh kyai ataupun santri. Komunikasi jenis interpersonal dianggap paling efektif dalam hal upaya mengubah sikap, pendapat atau perilaku seseorang karena sifatnya dialogis, berupa percakapan (Effendi, 2002: 8).

Di pesantren, santri sangat memengang teguh etika berkomunikasi interpersonal dengan sang kyai. sebagaimana yang tegaskan oleh Iin, bahwa santri harus memakai pakaian yang sopan ketika akan bertemu kyai. Bertemu dengan kyai memakai pakaian sopan adalah bentuk ketakziman komunikasi interpersonal seorang santri kepada kyai. Ketakziman santri kepada kyai merupakan bagian tradisi komunikasi di pesantren Bustanul Wildan. Ketakziman itu bisa terlihat dari perilaku santri yang tidak berani memulai pembicaraan sebelum kyai yang bertanya (verbal) dan mengunakan kopiah serta sarung saat berkujung kerumah kyai (nonverbal).

Komunikasi interpersonal kyai dengan santri mempunyai dimensi hubungan yang sangat dekat. Saat proses komunikasi interpersonal Kyai menganggap santri sebagai anaknya, sedangkan santri menganggap kyai sebagai orang tua mereka. Sebagaimana yang disampaikan oleh kang sepuh bahwa santri itu adalah anak titip dari Allah dan harus dijaga 
seperti anak sendiri. Maka dari itu, kedekatan hubungan santri akan mempengaruhi cara komunikasi interpersonal kyai kepada santri dan begitu juga sebaliknya.

Komunikasi interpersonal santri dengan kyai adanya rasa segan saat berkomuniaksi. Berbeda dengan komunikasi interpersonal kyai kepada santri. Komunikasi interpersonal kyai begitu terbuka dan juga sangat mendominasi daripada komunikasi interpersonal santri. adanya dominasi dari satu komunikator, seperti yang dijelaskan Mulyana dalam bukuanya, bahwa dalam komunikasi interpersonal sering kali ada yang mendominasi.

Di pesantren Bustanul Wildan keunikan Komunikasi interpersonal santri dengan kyai selalu didominasi oleh satu pihak, yaitu kyai. didominasinya pesan komunikasi interpersonal kyai dari santri karena dalam pimikiran santri tidak hormat jika banyak bicara atau banyak bertanya kepada kyai. Maka dari itu, komunikasi interpersonal santri dengan kyai selalu didominasi oleh kyai.

Komunikasi interpersonal santri dengan kyai di pesantrren ada yang bersifat diadik dan kelompok kecil. Bersifat diadik yaitu komunikasi interpersonal yang hanya dua orang saja, yaitu santri dengan kyai. sedangkan komunikasi kelompok kecil yaitu dua atau tiga santri yang berkomunikasi dengan kyai. sebagaimana yang di jelaskan oleh Canggara, bahwa dalam komunikasi interpersonal ada bersifat diadik dan kelompok kecil.

Pesan komunikasi interpersonal antara kyai dan santri bersifat langsung dan isi pesan tersebut nasehat-nasehat kepada santri. bahkan, sering kali kyai mengutip kata-kata dari kitab untuk nasehatkan kepada santri yang berisalaturrahmi kerumah beliau. Pesan-pesan komunikasi yang berupa nasehat merupakan komunikasi interpersonal kyai dalam penyebaran agama Islam kepada santrinya. Penyebaran agama bukan saja saat santri sedang dalam proses pembelajaran formal akan tetapi saat proses pembelajaran nonformal seperti saat komunikasi interpersonal berlangsung.

Simbol-simbol komunikasi interpersonal akan terlihat saat proses komunikasi interpersonal antara kyai dengan santri. Ketika berhadapan dengan sang kyai santri melihatkan budaya komunikasi yang unik yaitu, duduknya santri lebih rendah dari posisi duduknya kyai. Tujuan duduk lebih rendah dari pada kyai adalah semata-mata bentuk ketakziman santri kepada sang kyai saat proses komunikasi berlangsung.

Komunikasi kelompok antara kyai dengan santri. Komunikasi kelompok adalah komunikasi yang berlangsung antara beberapa orang dalam suatu kelompok kecil seperti dalam rapat, pertemuan, diskus dan 
sebagainya . Di lingkungan pesantren Bustanul Wildan komunikasi kelompok sering ditemui. Komunikasi kelompok di pesantren Bustanul Wildan lebih kepada kelompok primer. Kelompok primer kelompok yang mempunyai kedekatan begitu kuat dan anggotanya berhubungan akrab dengan satu anggota dengan anggota yang lain. Hubungan dekat ini adalah antara santri dengan kyai dan santri dengan sesama santri.

Komunikasi kelompok Pesantren dalam penyebaran agama Islam adalah melalui pengajian rutin harian, mingguan dan tahunan yaitu badongan, pasaran dan pengajian mingguan. Proses pengajian santri berkumpul di rumah kyai ataupun di mesjid. Komunikasi kelompok melalui pengajian rutin badongan merupakan komunikasi kelompok secara langsung, dimana dalam sistem pengajian badongan santri dan kyai saling bertatap muka. Seperti yang diungkapkan Effendy dalam bukunya bahwa komunikasi langsung berlangsung antara komunikator dengan komunikan saling berhadapan dan saling melihat.

Pesan komunikasi kelompok kyai saat proses pengajian mengunakan pesan yang bersifat edukatif. Pesan komunikasi kelompok mengutip dari kitab-kitab yang ajarkan. Pesan komunikasi kelompok bersifat langsung dimana kyai tidak mngunakan media elektronik sebagai pendukung. Proses komunikasi kelompok kyai mengunakan simbolsimbol komunikasi. Simbol - simbol .

Proses komunikasi kelompok, kyai sering mengunakan bahasa komunikasi nonverbal. Salah satu komunikasi nonverbal itu berupa diamnya kyai. Diamnya kyai merupakan simbol marahnya kyai kepada santri (partisipan) atas terlambat datang saat pengajian. Dengan bahasa nonverbalnya kyai mengirimkan pesan ketidaksukaan atas keterlambatan santri. selain itu, bahasa verbal komunikasi kelompok kyai saat pengajian merupakan adanya bahasa sindirian kepada santri.

Komunikasi intrapersonal dan kelompok merupakan salah satu interaksi yang ada di pesantren Bustanul Wildan. Peran interaksi intrapersonal dengan kelompok sangat bekontribusi besar dalam penyebaran agama Islam kepada santri. komunikasi interpersonal berupa silaturrahmi kerumah kyai sedangkan komunikasi kelompok berupa pengajian seperti badongan, pasaran maupun pengajian rutin mingguan.

Aktivitas interaksi antara komunikasi interpersonal dan kelompok sebagai salah tranformasi nilai-nilai budaya yang melekat di pesantren tradisional. Tranformasi nilai-nilai itu adalah melihat Peran kyai dalam mendidik para santri melalui interaksi yang dilakukan setiap

392 Ilmu Dakwah: Academic Journal for Homiletic Studies, Vol 10 No 2 | Juli-Des 2016 
harinya. Dua Komunikasi kelompok ini merupakan salah satu aktivitas budaya pesantren tradisional dalam penyebaran agama Islam.

Teori identitas merupakan penghubung utama antara individu dan masyarakat serta komunikasi merupakan mata rantai memperoleh hubungan ini terjadi. tentu, identitas adalah "kode" yang mendifinisikan keanggotaan dalam komunikasi yang beragam Identitas selain itu Teori indentitas komunikasi menjelaskan bahwa Komunikasi merupakan alat untuk membentuk identitas dan juga merubah mekanisme. Identitas diri, baik dalam dalam pandangan diri maupun orang lain, dibentuk ketika secara sosial berinteraksi dengan orang lain.

Indentitas pesantren tradisional Bustanul Wildan mempunyai ciri khas tersendiri, Salah satu yang sering dikenal identitas seorang santri adalah keilmuan agama yang mendalam, sifat kesedarhanaan ,disiplin, bertanggung jawab dan penuh hormat kepada orang tua dan guru. Selain itu,. Identitas itu sangat erat dengan atribut yang dikenakan dalam kesehariannya. Identitas para santri dan kyai pesantren Bustanul Wildan yang sangat mudah diidentifikasi seperti selalu sarung,kopiah,sorban (yang dipakai kyai dan santri) jelbab dan rok ( yang sering dipakai oleh santri putri) dan lainya. Sokamto mengatakan dalam bukunya, bahwa tradisi identitas Pesantren tradisional bisa di lihat dari santri sarungan.

Identitas personal santri dan kyai Bustanul Wildan adalah seorang santri dan kyai yang mahir dalam membaca kitab-kitab klasik (kitab kuning). Selain identitas santri sangat hebat dalam keilmuan umum dan agama dikarenakan masyoritas santri-santri Bustanul Wildan merupakan mahasiswa-mahaiswi yang mondok sambil kuliah di universitas (UIN,UNPAD,STIkes dll) yang ternama.

Karena itu, keunikan identitas santri Bustanul Wildan mempunyai identitas keilmuan umum dan agama yang mempuni. Dua keilmuan tentang keagamaan dan umum diintergrasikan, yang pada akhirnya akan menjadikan santri yang mempunyai intelektualitas dan sprituatitas yang hebat dan bisa bertahan terhadap perkembangan jaman. Adapun identitas personal kyai di pesantren Bustanul Wildan dikenal dengan karismatik yang dimilikinya. Identitas karismatik yang dimiliki oleh kyai menjadikan para santri begitu takzim kepada kyai.

Letteljhon dalam bukunya mengatakan, bawah Identitas personal didasarkan pada keunikan karakteristik pribadi seseorang. Perilaku budaya, suara, gerak-gerik anggota tubuh, dan pakaian, menunjukkan ciri khas seseorang yang tidak dimiliki seseorang. Identitas Kehidupan dipesantren Bustanul Wildan yang berhubungan dengan suara dan geragerik tubuh dan pakaian mempunyai ciri khas tersendiri. 
Gerak gerik tubuh Santri Bustanul Wildan akan menghindar jika bertemu dengan kyai, Santri tidak akan berani menatap mata kyai saat berkomunikasi. Sedangkan identitas marahnya kyai adalah dengan "diamnya". Identitas juga terlihat dari apa yang dipakai mereka. salah satu identitas santri Bustanul Wildan adalah berupa atribut yang dipakai kyai dan santri seperti sarung, surban, kopiah dan lainya. semua itu menjadi identitas tersendiri yang ada dipesantren Bustanul Wildan.

Salah satu identitas komunikasi yang mengikat seseorang adalah identitas komunalnya. Sebagaimana yang dijelaskan oleh Hacth dalam letteljhon, bahwa tingkatan komunal yang diikat pada kelompok atau budaya yang lebih besar. Tingkatan komunal tersebut adalah sistem kepercayaan, sistem pengajaran dan juga tradisi-tradisi yang telah turun temurun dari genarasi kegenerasi.

Sistem kerpercayaan pesantren Bustanul Wildan adalah ablussunnah wajamaah (NU). para santri baru dan masyarakat yang memasuki area pesantren Bustanul Wildan akan diikat dengan kepercayaan NU. Bahkan, tradisi-tradisi yang dikembangkan oleh pesantren Bustanul wilda adalah tradisi masyarakat NU, seperti Yasinan, Muludan, rajaban, tahlilan dan banyak lagi. begitu juga dengan sistem pengajaranya yang masih mengunakan sistem badongan dan sorogan yang menjadi identitas komunal pesantren.

Pada akhirnya, identitas yang ada dipesantren Bustanul Wildan merupakan ciri khas unik yang tidak sama dengan identitas pesantren lainya. Identitas ini dibagun dari interaksi antara individu dan kelompok yang sudah hidup bersama dalam waktu yang lama. Dari identitas pesantren tradisional dalamberdakwah akan menjadi ciri khas yang unik, yang tidak sama dengan komunikasi dakwah pesantren modern dan sekolah formal lainya.

\section{PENUTUP}

Pesantren Bustanul Wildan dalam penyebaran agama Islam yaitu pola komunikasi aksi, interaksi dan transaksi. Pola komunikasi aksi terjadi dalam proses berbelajaran badongan dan pasaran yang bersifat satu arah dari kyai kepada santri. sedangkan pola komunikasi interaksi berlangsung dalam proses pembelajaran sorogan. Pola komunikasi interaksi menunjukkan adanya feed back berupa respon dari partisipan komunikasi antara kyai dan santri. Selain itu, budaya pola komunikasi interaksi ini lebih dominan diperankan oleh kyai daripada santri. ada pun

394 Ilmu Dakwah: Academic Journal for Homiletic Studies, Vol 10 No 2 | Juli-Des 2016 
yang terakhir adalah pola komunikasi transaksi, yaitu ketika adanya pengajian bahtsa'ul masa'il. Pola komunikasi transaksi ketika saling mempengaruhi satu sama lain atau komunikasi banyak arah.

Bentuk komunikasi pesantren tradisional Bustanul Wildan dalam penyebaran agama Islam adalah komunikasi interpersonal dan komunikasi kelompok. Komunikasi interpersonal merupakan komunikasi yang bertatap muka secara langsung antara kyai dengan santri melalui kegiatan silaturrahmi dan minta doa. Adapun bentuk komunikasi kelompok yang ada di pesantren Bustanul Wildan adalah komunikasi yang dilakukan dalam acara pengajian dan pembelajaran di pesantren.

Diantara penemuan penting penelitian ini menunjukan bahwa ada faktor lain yang mempunyai peran penting dalam komunisi dakwah pesantren, yaitu pengaruh kyai dan aktivitas komunikasi di pesantren. faktor-faktor tersebut menjadi pertimbangan untuk komunikasi dakwah yang ada dipesantren. maka keberadaan kyai dalam pesantren tradisional merupakan yang esensial bagi keberlangsung dakwah di pesantren tradisional. Maka itu disarankan untuk peneliti selanjutnya, meneliti tentang komunikasi kyai dalam pembentukan tradisi Pesantren.

\section{DAFTAR PUSTAKA}

Abdulkadir Muhammad. Ilmu Sosial Budaya Dasar. Bandung: PT Citra Aditya Bakti, 2005.

Ainurrafiq Dawam dan Ahmad Ta'arifin. Manajemen Madrasah Berbasis Pesantren. Jakarta: Listafariska Putra, 2005.

Abdurrahman Soleh. Penyelenggaraan Mandrasah Pesantren. Jakarta: Dharma Bakti, 1985.

Alex Sobur. Semiotika Komunikasi. Bandung: PT Remaja Rosdakarya,2009.

Alo Liliweri. Komunikasi verbal dan Nonverbal. Bandung: PT Citra Aditya Bakti, 2008.

Asep Samuh, Komunikasi Dakwah teori, pendekatan dan aplikasi. Bandung: Simbiosa Retama 2012.

Asmuni Syukir, Dasar-dasar Strategi Dakwah Islam, Surabaya.: Al Ikhlas, Surabaya.1989.

Badrut sholeh. Abdurrahman Mas'ud. Budaya damai komuniktas pesantren. Jakarta: pustaka LP3ES Indonesia. 2007.

Dedy N. Hidayat, Paradigma dan Metodologi Penelitian Sosial Empirik Klasik. Jakarta: Departeman Ilmu komunikasi FISIP Universitas Indonesia, 2003. 
Deddy Mulyana dan Jalaluddin Rakhmat. Komunikasi Antar Budaya. Bandung: PT Rosda Karya, 2006.

Deddy Mulyana. Komunikasi Efektif: Suatu Pendekatan Lintas Budaya. Bandung:Rosda Karya, 2005.

Deddy Mulyana. Ilmu komunikasi: suatu pengatar. Bandung:Rosda Karya, 2007.

Elvinaro Ardianto. Metodologi Penelitian untuk Publik Relation Kuantitatif dan Kualitatif. Bandung, Remaja Rosdakarya, 2010.

Geoge Ritzer and Douglas J. Goodman . Teori Sosiologi Modern. Jakarta: Kencana, 2010.

Harimanto dan Winarno. Ilmu Sosial dan Budaya Dasar. Jakarta: PT Bumi Aksara 2013.

Hafied Cangara. Pengantar Ilmu Komunikasi. Jakarta: PT Raja Grapindo Persada, 2012.

Jama'an Santori \& Aan Komariah. Metodelogi Penelitian Kualitatif. Bandung: Alfabeta 2012.

Koentjanigrat. Pengantar Ilmu Antropoloogi. Jakarta: PT. Rineka Cipta, 2000.

Faisal Muzzammil dkk. Makalah: Budaya Komunikasi Masyarakat Modern. Bandung: 2014.

Lexy J. Moleong.Metodologi Penelitian Kualitatif. Bandung: Remaja Rosdakarya, 2009.

Larri Samovar, Richard E. Porter dan Edewin R. Mcdaniel. Komunikasi Lintas Budaya, Jakarta: Salemba Humanika, 2014.

M. Munandar Soelaeman. Ilmu Budaya Dasar: Suatu Pengantar. Bandung: PT Refika Aditama 2010.

Morissan dan Andy Corry Wardhany. Teori komunikasi. Bogor: Ghalia Indonesia, 2009.

M Quraisy Shihab. Wawasan Al Qur'an. Bandung: Mizan, 1996.

Nina W. Syam. Sosiologi Sebagai Akar Imu Komunikasi, (Bandung:Simbiosa Rakatama media, 2009.

Onong Uchjana Effend.. Dinamika Komunikasi,Bandung: PT Remaja Rosdakarya, 2002.

Peter Salim dan Yenny Salim. Kamus Bahasa Indonesia. Surabaya: Arkola, 1991.

Rachmat Kriyantono, Teknik praktik riset komuniksi, Jakarta: kencana prenada media group, 2012

Riswandi. Ilmu Komunikasi.Yogyakarta: Graha Ilmu, 2009.

396 Ilmu Dakwah: Academic Journal for Homiletic Studies, Vol 10 No 2 | Juli-Des 2016 
Rosady Rulan. Metode Penelitian Public Relations dan Komunikeasi, Jakarta: Rajawali Pers, 2010.

Robert K. Yin. Studi kasusk desain \& metode. Jakarta: Raja Grafindo Persada, 2013.

Samsul Ismail. Dinamika Pesantren dan Madrasah. (Pustaka Pelajar. Celeban Timur, Yogyakarta. 2002).

Sokamto. Kepemimpinan Kiai Dalam Pesantren, Jakarta: Pustaka LP3ES, 1999.

Sulasman dan Setia Gumiliar, Teori-Teori Kebudayaan dari Teori hingga aplikasi, Bandung: Pustaka Setia, 2013.

Stewart L. Tubbs dan Sylvia Moss. Human Communication Konteks-Konteks Komunikasi. Bandung: PT Remaja Rosdakarya, 2010.

Soerjono Soekanto. Sosiologi Suatu Pengatar. Jakarta: PT RajaGrafindo Persada, 2005.

Sulthon Masyhud dan Moh.Khusnurdilo. Manajemen Pondok Pesantren, Jakarta:Diva Pustaka, 2003.

Stephen W. Littlejohn and Karen A. Foss. Theories Of Human Communication. (Jakarta: selemba Humanika. 2008.

Tim Penyusun, 2014, Panduan Penulisan dan Disertasi Program Pascasarjana UIN SGD Bandung, Bandung,

Wahyu Ilahi, komunikasi Dakwah. Bandung: Rosdakarya, 2010

Zamakhsyari Dhofier. Tradisi Pesantren: Studi pendangan bidup kyai dan visisnya mengenai masa depan Indonesia. Jakarta: LP3ES, 2011.

bttp:/ / id.wikipedia.org/wiki/Budaya 